\title{
Identification of toxigenic Aspergillus species from diet dairy goat using a polyphasic approach
}

\author{
Identificação de espécies toxigênicas de Aspergillus isoladas da \\ dieta de cabras leiteiras utilizando uma abordagem polifásica
}

\author{
Janaina Lara da Silva ${ }^{I}$ Christiane Ceriani Aparecido ${ }^{I I}$ Daiane Hansen ${ }^{I}$ \\ Tacila Alves Muniz Pereira ${ }^{I}$ Joana D'arc Felicio $^{\mathrm{I}}$ Edlayne Gonçalez $^{\mathrm{I}^{*}}$
}

\begin{abstract}
Some species of filamentous fungi that infest agricultural commodities are able to produce mycotoxins, contaminating feed and animal products. The aim of this research was to identify the mycoflora present in the feed and forage for dairy goat and to isolate and characterize the Aspergillus flavus and A. parasiticus strains based on a morphological and molecular characterization and mycotoxigenic ability. The goat dairy diets were collected monthly from 11 goat milk farms, totaling 129 and 106 samples of concentrate and forage, respectively. For the isolation of the mycobiota the surface plating method was used. Aspergillus, Penicillium, and Fusarium were the main fungi producing mycotoxins isolated. The morphological and molecular characterization and mycotoxigenic ability were used for A. flavus and $\boldsymbol{A}$. parasiticus identification. The Aspergillus spp. from feed $39 \%$ produced aflatoxins $B_{1}$ and $B_{2}, 17 \%$ produced cyclopiazonic acid (CPA), $18 \%$ produced both toxins, and $42 \%$ had no toxigenic ability. Only $2.0 \%$ of the strains produced aflatoxins $B_{1}, B_{2}, G$ and $G_{2}$, but no CPA. The strains from forage were producers of aflatoxins $B_{1}$ and $B_{2}(37 \%), C P A(14 \%), 14 \%$ of both mycotoxins, whereas $49 \%$ have shown no toxigenic ability. The aflD and afR genes were used by PCR and PCR-RFLP, respectively. The presence of toxigenic species in samples of feed for lactating goats indicates a potential risk of contamination of dairy products, if they are exposed to environmental conditions favorable to fungal growth and mycotoxin production.
\end{abstract}

Key words: toxigenic fungi, aflatoxin, cyclopiazonic acid, feed, molecular characterization.

\section{RESUMO}

Algumas espécies de fungos filamentosos que infestam os produtos agrícolas e ração são capazes de produzir micotoxinas. O objetivo deste trabalho foi identificar a micoflora presente nos concentrados e volumosos utilizados na dieta de cabras leiteiras e isolar as espécies Aspergillus flavus e A.

\begin{abstract}
parasiticus, com base em uma caracterização morfológica e molecular e capacidade micotoxigênica. Os alimentos foram coletados mensalmente em 11 fazendas produtoras de leite de cabra, totalizando 129 e 106 amostras de concentrado e volumoso, respectivamente. Para o isolamento da micobiota, foi utilizado o método de plaqueamento de superficie. Aspergillus, Penicillium e Fusarium foram os principais gêneros de fungos produtores de micotoxinas isolados das amostras. A caracterização morfológica e molecular e capacidade micotoxigênica foram utilizadas para identificação de A. flavus e A. parasiticus. Das cepas Aspergillus spp isoladas do concentrado, $39 \%$ produziram aflatoxinas $B_{1}$ e $B_{2}$, $17 \%$ produziram ácido ciclopiazônico $(A C P), 18 \%$ produziram ambas as toxinas e $42 \%$ não tinham capacidade toxigênica. Apenas 2,0\% das cepas produziram aflatoxinas $B_{1}, B_{2}, G_{1} e$ $G_{2}$. As cepas de Aspergillus spp. isoladas do volumoso foram produtores de aflatoxinas $B_{1}$ e $B_{2}(37 \%), A C P(14 \%)$, sendo que $14 \%$ produziram ambas toxinas e $49 \%$ não foram produtoras. $O S$ genes aflD e aflR foram utilizados para a PCR e a PCR-RFLP, respectivamente. A presença de espécies toxigênicas em amostras de alimentos destinados a caprinos em lactação indica um risco potencial de contaminação dos produtos lácteos por aflatoxinas e ACP, caso estes sejam expostos a condições ambientais favoráveis ao crescimento de fungos e produção de micotoxinas.
\end{abstract}

Palavras-chave: fungos toxigênicos, aflatoxinas, ácido ciclopiazônico, ração, caracterização molecular.

\section{INTRODUCTION}

The complex diet of ruminants, consisting of forages, concentrates, and silages, can be a source of diverse mixture of mycotoxins that contaminate individual feed components (SMITH \& KOROSTELEVA, 2012). Both, feed grains (e.g.

ICentro de Pesquisa e Desenvolvimento de Sanidade Animal (CPDSA), Instituto Biológico, Av. Conselheiro Rodrigues Alves, 1252,

04014-002, São Paulo, SP, Brasil. E-mail: goncalez@biologico.sp.gov.br. "Corresponding author.

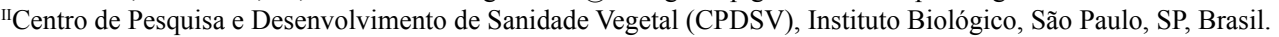


corn, wheat, barley, cottonseed) and forages support fungal growth that leads to mycotoxin production (OSWEILER, 2012). MORETTI et al. (2013) emphasize the importance of knowledge of biodiversity of toxigenic fungi to better understand factors that contribute to mycotoxin production, assessment of risks posed by mycotoxigenic fungi, and reduction of mycotoxin contamination in feed and food crops. The mycotoxigenic fungi involved in the food and feed chain belong mainly to the Aspergillus, Penicillium, Fusarium and Alternaria genera. Aspergillus section Flavi includes three species, A. flavus, A. parasiticus and $A$. nomius, producers of aflatoxins, highly toxic compounds of concern in food safety. A. flavus also produces other mycotoxin such as cyclopiazonic acid (CPA) (VAAMONDE et al., 2003). The identification of Aspergillus Section Flavi has been traditionally based on morphological and biochemical characterization. Conidial wall ornamentation is regarded as the primary morphological diagnostic character for separation of Aspergillus flavus and $\boldsymbol{A}$. parasiticus. The mycotoxigenic profile (regarding aflatoxins $B$ and $G$ and CPA) of these strains has been routinely used for identification (RODRIGUES et al., 2009). Molecular techniques have been used to differentiate these two species (SOMASHEKAR et al., 2004; RODRIGUES et al., 2009). However, it is to be emphasized that the PCR detection of $\boldsymbol{A}$. flavus, A. parasiticus or A. nomius is no guarantee of aflatoxin production since gene other than those involved in the biosynthesis of aflatoxins are not target for amplification (LEVIN, 2012). The State of São Paulo has environmental factors conducive to the consolidation of goat and sheep production, and the scientific and technological advances contribute to increased rates of production and productivity of animals. Since the aflatoxins and CPA can be toxic compounds of concern in milk, it is very important to offer a quality feed for dairy goats. So, the aim of this work was to identify the mycoflora present in the feed and forage for dairy goat and isolate and characterize the $\boldsymbol{A}$. flavus and $\boldsymbol{A}$. parasiticus strains based on a polyphasic approach involving morphological and molecular characterization, and mycotoxigenic ability.

\section{MATERIAL AND METHODS}

\section{Samples}

The samples of dairy goat feed (129) and forage (106) were collected from May, 2010 to September, 2011, once a month from 11 farms producing goat milk located in the cities of Ibiúna, Piedade, Alambari, Capão Bonito, Guareí, and Porto Feliz, in São Paulo State, Brazil. In the properties, feed and forage were packed in barrels with a capacity of $20 \mathrm{~kg}$ each. Samples of the feed and forage were collected at nine different points of each barrel: three points of the upper third, three points of the middle third and three points of the lower third (SASSAHARA et al., 2003). Each sample contained a minimum of $500 \mathrm{~g}$. The collected material was homogenized and stored in plastic packaging and sent to the laboratory for isolation and identification of the mycoflora and water activity analysis.

Identification and enumeration of the mycobiota from goat feed and forage

The animal feed and forage samples were apportioned in $10 \mathrm{~g}$ aliquots and homogenized for 30 minutes in bottles containing $90 \mathrm{~mL}$ of sterile distilled water. Aliquots with $0.1 \mathrm{~mL}$ of the dilutions in serial from $10^{-1}$ to $10^{-6}$ of the samples were plates in duplicate using the surface methods in potato agar dextrose (PDA) medium. The plates were incubated at $25^{\circ} \mathrm{C}$ for 5 days, but the observations were made daily. The colonies were identified at the genus level, and those belonging to the genus Aspergillus were identified at the species level according to PITT \& HOCKING (1997).

\section{Molecular Characterization of A. flavus and $\boldsymbol{A}$. parasiticus \\ DNA extraction}

The strains characterized as the genus Aspergillus (233) were submitted to molecular identification. The strains of $\boldsymbol{A}$. favus and $\boldsymbol{A}$. parasiticus were maintained in a tube containing PDA at $25^{\circ} \mathrm{C}$ at 7 days, and a loop full of spores from each strain was transferred to $1.5 \mathrm{~mL}$ of lysis buffer with $1.0 \mathrm{~g}$ of sterile acid-washed 0.4 to $0.6 \mathrm{~mm}$ diameter glass beads and vortexed for $5.0 \mathrm{~min}$ at maximum speed. Proteins and polysaccharides were precipitated by $750 \mu \mathrm{L}$ of cold $3 \mathrm{M}$ sodium acetate, $\mathrm{pH}$ 5.5. The solution was mixed, placed at $-20^{\circ} \mathrm{C}$ for $10 \mathrm{~min}$ and centrifuged at $5000 \mathrm{~g}$ for $10 \mathrm{~min}\left(4^{\circ} \mathrm{C}\right)$ for twice. The supernatant was precipitated with one volume of cold isopropanol. The solution was mixed gently, incubated for $1.0 \mathrm{~h}$ at $-20^{\circ} \mathrm{C}$ and centrifuged at $5000 \mathrm{~g}$ for $10 \mathrm{~min}$ at $4^{\circ} \mathrm{C}$. DNA pellet was washed twice with $1.0 \mathrm{~mL}$ of cold $70 \%$ ethanol, centrifuged at $5000 \mathrm{~g}$ for $5 \mathrm{~min}$ at $4^{\circ} \mathrm{C}$. DNA was diluted in $100 \mu \mathrm{L}$ of ultrapure water and stored at $-20^{\circ} \mathrm{C}$ (RODRIGUES et al., 2009). The DNA was quantified by measuring the absorption at $260 \mathrm{~nm}$ in a Hitachi U-2000 spectrophotometer.

PCR amplification of aflD gene

The gene $a f D$ was tested for all strains and the aflD primers were specifically designed according 
to the described by RODRIGUES et al. (2009). The PCR amplifications were performed using about $1 \mu \mathrm{g}$ of fungal template DNA, 200 pmol of each primer (Nor1Forward: 5'-ACC GCT ACG CCG GCA CTC TCG GCA C-3' and Nor2-Reverse: 5'-GTT GGC CGC CAG CTT CGA CAC TCC G-3'), $\mathrm{MgCl}_{2}$-free reaction buffer, $2.0 \mathrm{mM} \mathrm{MgCl}, 2.5 \mathrm{U}$ of Taq polymerase and $0.2 \mathrm{mM}$ of each dNTP. PCR was carried out under the following conditions: one cycle at $94^{\circ} \mathrm{C}$ for $3 \mathrm{~min} ; 30$ cycles at $94^{\circ} \mathrm{C}$ for $1 \mathrm{~min}$, at $55^{\circ} \mathrm{C}$ for $1 \mathrm{~min}$ and at $72^{\circ} \mathrm{C}$ for $1 \mathrm{~min}$; and at $72^{\circ} \mathrm{C}$ for $10 \mathrm{~min}$ in a final extension.

Restriction site analysis of PCR products After analysis of PCR products by amplification of afD gene, only the samples positive for Aspergillus fungi were used in the restriction site analysis. First, a new PCR was used to amplify two target fragments on A. flavus and A. parasiticus, and the aflR primer sequences were designed according to the described by SOMASHEKAR et al. (2004) to amplify a fragment of 796pb (aflR1-Forward: $5^{\prime}$-AAC CGC ATC CAC AAT CTC AT-3' and aflR2-Reverse: 5'-AGT GCA GTT CGC TCA GAA CA-3'). The reaction mixture consisted of $1.0 \mu \mathrm{g}$ of fungal template DNA, 50pmol of each primer, $\mathrm{MgCl}_{2}$-free reaction buffer, $2.0 \mathrm{mM} \mathrm{MgCl}_{2}, 0.5 \mathrm{U}$ of Taq polymerase and $0.2 \mathrm{mM}$ of each dNTP. PCR was carried out under the following conditions: one cycle at $94^{\circ} \mathrm{C}$ for $5 \mathrm{~min} ; 30$ cycles at $94^{\circ} \mathrm{C}$ for $3 \mathrm{~min}$, at $50^{\circ} \mathrm{C}$ for $1.25 \mathrm{~min}$ and at $72^{\circ} \mathrm{C}$ for $1.40 \mathrm{~min}$; and at $72^{\circ} \mathrm{C}$ for $10 \mathrm{~min}$ in a final extension. Then, the PCR products were digested with HincII to analyze the restriction site. Each restriction reaction contained $10 \mu \mathrm{L}$ of PCR product

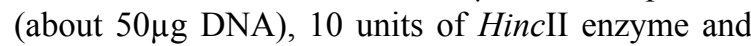
$2.0 \mu \mathrm{L}$ of $10 \mathrm{x}$ digestion buffer as recommended by the manufacturer. The reaction mixture was incubated at $37^{\circ} \mathrm{C}$ for $4 \mathrm{~h}$. The sample was frozen and dried in nitrogen gas. After, the precipitate was dissolved in $10 \mu \mathrm{L}$ of water, and the resulting fragments were separated by electrophoresis on a $1.5 \%$ agarose gel. The primers were synthetized by Bioneer Corporation, South Korea, and all other reagents used in PCR and restriction analysis were purchased by Fermentas, Lithuania, part of Thermo Fisher Scientific.

Toxigenic potential of $\boldsymbol{A}$. flavus and $A$. parasiticus strains for aflatoxins

The production of aflatoxins was tested using the method of LIN \& DIANESE, 1976. The $\boldsymbol{A}$. flavus strains isolated from goat feed (130) and from forage (70) were maintained in a tube containing PDA at $25^{\circ} \mathrm{C}$ for 5 days. A fragment of each colony was then inoculated into a place containing coconut agar medium and incubated at $25^{\circ} \mathrm{C}$ for 10 days. After growth, the whole content of each plate was removed, and chloroform was added, $30 \mathrm{~mL}$ for each $10 \mathrm{~g}$ of culture. After shaking, the sample was filtered through filter paper with diatomaceous earth and sodium sulfate. The filtrated was evaporated, and the extract was suspended in chloroform and then submitted to thin layer chromatography (TLC).

\section{Aflatoxin analyses}

The aflatoxins identification and quantification were performed by TLC using an aliquot $(40 \mu \mathrm{L})$ of each sample, which was spotted on silica gel-G thin layer plate (Merck, Germany) and then developed with chloroform:acetone 9:1 (v/v) as a solvent system. The concentration of aflatoxins was determined by photodensitometry (Shimadzu, CS 9000) comparing the area and density of the spot samples with aflatoxins $B_{1}, B_{2}, G_{1}$ and $G_{2}$ standards (Sigma Aldrich, USA) (GONÇALEZ et al., 2001). The detection e quantification limits were established how the lowest fluorescence detectable signal and the lowest concentration measured, respectively. The detection and quantification limits for $\mathrm{AFB}_{1}$ were $0.8 \mathrm{ng} \mathrm{g}^{-1}$ and $1.6 \mathrm{ng} \mathrm{g}^{-1}$, respectively. Recovery for standard aflatoxin $\mathrm{B}_{1}$ should be at least $94 \%$.

\section{Toxigenic potential of $\boldsymbol{A}$. flavus strains for CPA}

The methodology of GONÇALEZ et al. (2013) was employed to evaluate the CPA production by $\boldsymbol{A}$. flavus strains. The $\boldsymbol{A}$. flavus strains isolated from goat feed (130) and from forage (70) were maintained in a tube containing PDA at $25^{\circ} \mathrm{C}$ for 7 days. Spore solutions $(1.0 \mathrm{~mL})$ of each sample were inoculated into $25 \mathrm{~mL}$ of Czapec-Dox broth (Difco) and incubated for 12 days at $25^{\circ} \mathrm{C}$. The cultures were filtrated, and the CPA was extracted twice with $25 \mathrm{~mL}$ of chloroform. The chloroform was evaporated and the extract was diluted in $1.0 \mathrm{~mL}$ of methanol HPLC grade and then submitted to high performance liquid chromatography (HPLC).

\section{HPLC conditions}

The mobile phase consisted of methanol:

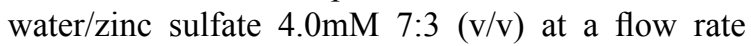
of $0.6 \mathrm{~mL} \mathrm{~min} \mathrm{~m}^{-1}$. A $\mathrm{C}_{18}$ column, $250 \mathrm{~mm} \times 4.6 \mathrm{~mm}$ (Shimadzu, Japan) was used, and the analyses were done with a UV detector at $284 \mathrm{~nm}$. The calibration curve was established by the external standard method with five concentrations: $0.611 ; 1.223 ; 2.446$; 4.892, and $9.798 \mu \mathrm{g} \mathrm{mL} \mathrm{mL}^{-1}\left(r^{2}=0.998\right)$. The HPLC quantification and detection limits for a standard CPA were $0.030 \mu \mathrm{g} \mathrm{mL}^{-1}$ and $0.005 \mu \mathrm{g} \mathrm{mL} \mathrm{m}^{-1}$, respectively. Recovery for standard CPA was $97 \%$. 
Water activity determination

The wateractivity $\left(\mathrm{a}_{\mathrm{w}}\right)$ of goat feed and forage samples was determined by automatic analysis using Aqualab 4TE (Decagon Devices Inc., Pullman, WA).

\section{Statistical analysis}

The results were analyzed by ANOVA and Tukey's multiple range tests with a significance level $\mathrm{P}<0.05$ to determine differences between feed and forage using the variables: fungi isolation, $\boldsymbol{A}$. flavus and $\boldsymbol{A}$. parasiticus identification, mycotoxigenic ability and $\mathrm{a}_{\mathrm{w}}$.

\section{RESULTS AND DISCUSSION}

An important component of efforts to control mycotoxin contamination problems is the study of the morphological, molecular genetics, metabolic and plant pathological diversity of mycotoxigenic fungi (MORETTI et al., 2013).

The mycoflora of the animal feed and forage samples are shown in table 1 . Toxigenic fungi belonging to the genera Aspergillus, Penicillium, and Fusarium were isolated from most samples (Table 1). Other studies also reported the presence of Aspergillus spp., Penicillium spp., Fusarium spp., and Eurotium spp. in animal feed (PEREYRA et al., 2010; ASTORECA et al., 2011). Among representatives of the genus Aspergillus, were isolated from animal feed: $\boldsymbol{A}$. flavus $(69 \%)$, A. fumigatus $(2.30 \%), A$. niger $(1.50 \%)$ and $A$. parasiticus $(0.80 \%)$. The highest incidence of $\boldsymbol{A}$. flavus was shown in animal feed and in their ingredients (PEREYRA et al., 2010 and 2011; ASTORECA et al., 2011). The Aspergillus species isolated from forage

Table 1 - Relative frequency (\%) of the genera fungi contamination of animal feed (129 samples) and forage (106 samples) collected in 11 dairy goat farms in the period May, 2010 to September, 2011.

\begin{tabular}{lcc}
\hline Isolated fungi & $\begin{array}{c}\text { Relative frequency } \\
(\%)\end{array}$ & $\begin{array}{c}\text { Relative frequency } \\
\text { (\%) in forage }\end{array}$ \\
\hline Penicillium spp. & 84.5 & 71.7 \\
Mucor spp. & 44.9 & 30.2 \\
Fusarium spp. & 35.6 & 32.0 \\
Aspergillus spp. & 34.1 & 43.4 \\
Cladosporium spp. & 33.3 & 34.9 \\
NSF* & 31.0 & 50.0 \\
Rhizopus spp. & 21.0 & 8.5 \\
Trichoderma spp. & 20.9 & 16.0 \\
Colletotrichum spp. & 8.5 & 26.4 \\
Eurotium spp. & 1.5 & 2.3 \\
Paecilomyces spp. & 0.8 & - \\
\hline
\end{tabular}

*NSF: Non-sporulating fungi. were: A. flavus (49\%), A. fumigatus (5.70\%), and A. niger (1.0\%). The forage samples showed highest incidence of Aspergillus spp. than in feed. Same results were found by ACCENSI et al. (2004). The identification of Aspergillus Section Flavi has been traditionally based on morphological and biochemical characterization (RODRIGUES et al., 2009). The morphological and molecular characterization and mycotoxigenic ability were used for A. flavus and A. parasiticus identification. Morphologically, A. flavus has finely roughened conidia mostly produced from heads bearing both metulae and phialides, whereas conidia of $\boldsymbol{A}$. parasiticus are usually conspicuously roughened and most heads bear phialides alone (PITT \& HOCKING, 1997). Based on these morphological characters, it was possible to identify A. flavus in $64 \%$ of the Aspergillus spp. isolated from feed and 37\% from the forage. The identification was confirmed by molecular characterization and mycotoxigenic ability of the A. flavus and A. parasiticus strains.

The results of the molecular analysis showed that $97 \%$ of the Aspergillus spp. isolated from feed was PCR positive for $\boldsymbol{A}$. flavus and $\boldsymbol{A}$. parasiticus. The molecular identification using the gene aflD (PCR) was a good maker for differentiating the A. flavus and A. parasiticus species (fragment of 400pb) from the other Aspergillus spp., but it was not possible to differentiate them from each other. Of 131 strains isolated from feed and confirmed by PCR, $65.60 \%$ were $A$. flavus and $0.76 \%$ was $\boldsymbol{A}$. parasitcus, using the gene aflR (PCR-RFLP). Among the Aspergillus spp. isolated from forage (98 strains) $71.40 \%$ were positive by PCR analysis and $51.40 \%$ of them were identified with $\boldsymbol{A}$. flavus, however $\boldsymbol{A}$. parasiticus was not isolated. The results obtained in this work are in agreement with SOMASHEKAR et al. (2004), who showed that PCR-RFLP patterns obtained with HincII can be used to distinguish the two species. A. flavus cleaved into 3 fragments of 385, 250, 161bp whereas $A$. parasiticus, having one restriction site for the HincII, produced 2 fragments of 546 and $250 \mathrm{bp}$. The aflD and aflR genes were not able to identify the ability of the strains to produce aflatoxins (SOMAHEKAR et al., 2004; RODRIGUES et al., 2009). In addition, the genomic structural genes involved in aflatoxins biosynthesis do not guarantee the production of aflatoxins by all isolates of A. flavus and A. parasiticus (LEVIN, 2012), so their mycotoxigenic ability was investigated. The 131 Aspergillus spp. strains confirmed by PCR from feed and 70 strains from the forage were evaluated as having ability to produce aflatoxins and CPA (Table 2). A. flavus is able to produce aflatoxins 
Table 2 - Aflatoxins $\mathrm{B}_{1}$ and $\mathrm{B}_{2}$ and CPA production in culture medium by Aspergillus spp. isolated from feed (131 strains) and forage (70 strains) collected in 11 dairy goat farms in the period May, 2010 to September, 2011.

\begin{tabular}{|c|c|c|c|c|}
\hline Mycotoxin & Number of isolates producer $(\%)$ & Range & Number of isolates producer $(\%)$ & Range \\
\hline $\mathrm{AFB}_{1}$ & $51(39)$ & $9.12-6,425.43 \mu \mathrm{g} \mathrm{kg}^{-1}$ & $26(37)$ & $8.35-2,944.74 \mu \mathrm{g} \mathrm{kg}^{-1}$ \\
\hline $\mathrm{AFB}_{2}$ & $16(12)$ & $7.56-87.18 \mu \mathrm{g} \mathrm{kg}^{-1}$ & $05(7)$ & $3.57-49.24 \mu \mathrm{g} \mathrm{kg}^{-1}$ \\
\hline CPA & $22(17)$ & $2.12-179.06 \mu \mathrm{g} \mathrm{mL}^{-1}$ & $10(14)$ & $4.10-123.92 \mu \mathrm{g} \mathrm{mL}^{-1}$ \\
\hline
\end{tabular}

$\mathrm{AFB}_{1}$ : aflatoxin $\mathrm{B}_{1} ; \mathrm{AFB}_{2}$ : aflatoxin $\mathrm{B}_{2} ; \mathrm{CPA}$ : cyclopiazonic acid.

and CPA, and $A$. parasiticus can produce only aflatoxins. The results showed that of the Aspergillus spp. from feed $39 \%$ produced aflatoxins $\mathrm{B}_{1}$ and $\mathrm{B}_{2}$, $17 \%$ produced CPA, $18 \%$ produced both toxins, and $42 \%$ had no toxigenic ability. Only $2.0 \%$ of the strains produced aflatoxins $B_{1}, B_{2}, G_{1}$ and $G_{2}$, but no CPA, and, based on all characteristics analyzed, they were identified with $A$. parasiticus. Almost all A. parasiticus isolated produce both aflatoxins B and G, but not CPA (HORN \& DORNER, 1999). The strains from forage were producers of aflatoxins $\mathrm{B}_{1}$ and $\mathrm{B}_{2}(37 \%)$, CPA $(14 \%), 14 \%$ of both mycotoxins, and $49 \%$ did no show toxigenic ability. The concentrations of aflatoxins $\mathrm{B}_{1}$ and $\mathrm{B}_{2}$, and CPA were showed in the table 2 . The results showed the great variability in the mycotoxins producing potential by A. flavus in the culture conditions. Our results agree with the literature that also found difference in the mycotoxigenic ability of the $\boldsymbol{A}$. flavus (VAAMONDE et al., 2003; ASTORECA et al., 2011). VAAMONDE et al. (2003) proposed five chemotypes for A. flavus species, based on the mycotoxins produced by them: chemotype I for aflatoxin B and CPA producers; II for AFB, AFG and CPA producers; III for AFB producers; IV for CPA producers and $\mathrm{V}$ for non mycotoxin producers. The A. flavus strains isolated from feed and forage belong to the following chemotypes, respectively: type I (18\% and $14 \%)$; type III $(39 \%$ and $37 \%)$; type IV (17\% and $14 \%$ ) and type V (25\% and 35\%). The chemotype II was not isolated. ASTORECA et al. (2011), also isolated A. flavus belonging to chemotypes I, III, IV and V, but no type II from poultry feed. By comparing the chemotypes isolated from feed and forage, there was no statically significant difference between them $(\mathrm{P}<0.05)$.

The average $a_{w}$ values of the samples ranged from 0.51 to 0.75 for feed and from 0.46 to 1.0 for forage. The minimum $\mathrm{a}_{\mathrm{w}}$ values required for growing $\boldsymbol{A}$. flavus and $\boldsymbol{A}$. parasiticus as well as for producing aflatoxins are 0.80 and 0.83 , respectively (PITT \& HOCKING, 1997). The $\mathrm{a}_{\mathrm{w}}$ did not influence the A. flavus and A. parasiticus isolation from feed and also forage $(\mathrm{P}<0.05)$ since these species were isolated in all samples analyses. Therefore, the feed did not have water enough for the fungal activity. On the other hand, the forage is not a good substrate, because it has high fiber concentration and low nutrients to the fungi.

According to SMITH \& MOSS (1985), feed with good microbiological quality should present a maximum of $10^{5}$ colony-forming units $\mathrm{g}^{-1}\left(\mathrm{CFU} \mathrm{g} \mathrm{g}^{-1}\right)$. The results showed that only $17 \%$ of the feed and $2.8 \%$ of forage samples had more than $10^{5} \mathrm{CFU} \mathrm{g}^{-1}$, therefore most of goat feeding had good quality in all farms studied.

\section{CONCLUSION}

The results obtained in this study indicate that, to distinguish the $\boldsymbol{A}$. flavus and $\boldsymbol{A}$. parasiticus species, it is necessary more than one technique of identification. The presence of $\boldsymbol{A}$. flavus capable of producing CPA and aflatoxins indicates a risk of contamination in dairy goat feed and forage if they are exposed to environmental conditions that allow fungal growth.

\section{ACKNOWLEDGEMENTS}

The authors are grateful to the Fundação de Amparo à Pesquisa do Estado de São Paulo (FAPESP) for financial support.

\section{REFERENCES}

ACCENSI, F. et al. Occurrence of Aspergillus species in mixed feeds and component raw materials and their ability to produce ochratoxin A. Food Microbiology, v.21, p.623-627, 2004.

ASTORECA, A.L. et al. A survey on distribution and toxigenicity of Aspergillus section Flavi in poultry feeds. International Journal of Food Microbiology, v.146, p.38-43, 2011.

GONÇALEZ, E. et al. Biflavonoids inhibit the production of aflatoxin by Aspergillus flavus. Brazilian Journal of Medical and Biological Research, v.34, p.1453-1456, 2001.

GONÇALEZ, E. et al. Produção de aflatoxinas e ácido ciclopiazônico por cepas de Aspergillus flavus isoladas de amendoim. Arquivos do Instituto Biológico, v.80, p.312-317, 2013. 
HORN, B.W.; DORNER, J.W. Regional differences in production of aflatoxin B1 and cyclopiazonic acid by soil isolates of Aspergillus flavus along a transect within the United States. Applied and Environmental Microbiology, v.65, p.1444-1449, 1999.

LEVIN, E.R. PCR detection of aflatoxin production fungi and its limitations. International Journal of Food Microbiology, v.156, p.1-6, 2012.

LIN, M.L.; DIANESE, L.C.A. Coconut agar medium for rapid detection of aflatoxin production by Aspergillus spp. Phytopathology, v.66, p.1466-1469, 1976.

MORETTI, A. Molecular biodiversity of mycotoxigenic fungi that threaten food safety. International Journal Food Microbiology, v.167, p.57-66, 2013.

OSWEILER, G.D. Equine mycotoxicosis. In: GONÇALEZ, E. et al. Mycotoxicoses in animals economically important. New York: Nova Science Publishers, 2012. Cap.1, p.1-34.

PEREYRA, C.M. et al. Fungi and mycotoxins in feed Intended for Sows at different reproductive stages in Argentina. Veterinary Medicine International, v.2010, p.569108, 2010.

PEREYRA, C.M. et al. Mycobiota and mycotoxins contamination in raw materials and finished feed intended for fattening pigs production in eastern Argentina. Veterinary Research Communication, v.35, p.367-379, 2011. Available from: <http:// link.springer.com/article/10.1007\%2Fs 11259-011-9483-9>. Accessed: Jun. 06, 2012. doi: 10.1007/s11259-011-9483-9.

PITT, J.I.; HOCKING, A.D. Fungi and food spoilage. New York: Springer, 1997. p. 506.
RODRIGUES, P. et al. A polyphasic approach to the identification of aflatoxigenic and non-aflatoxigenic strains of Aspergillus section Flavi isolated from portuguese almonds. International Journal of Food Microbiology, v.129, p.187-193, 2009. Available from: <http://www.sciencedirect.com/science/article/ pii/S0168160508006156>. Accessed: Jan. 27, 2010. doi:10.1016/j. ijfoodmicro.2008.11.023.

SASSAHARA, M. et al. Ocorrência de aflatoxina e zearalenona em alimentos destinados ao gado leiteiro na Região Norte do Estado do Paraná. Semina: Ciências Agrarias, v.24, p. 63-72, 2003.

SMITH, J.; MOSS, M. Mycotoxins, formation, analysis and significance. New York: John Wiley and Sons, 1985. p.223.

SMITH, T.K.; KOROSTELEVA, S.N. The significance of feedborne mycotoxins in ruminant nutrition. In: GONÇALEZ, E. et al. Mycotoxicoses in animals economically important. New York: Nova Science Publishers, 2012. Cap.2, p.35-66.

SOMASHEKAR, D. et al. PCR-restriction fragment length analysis of aflR gene for differentiation and detection of Aspergillus flavus and Aspergillus parasiticus in maize. International Journal of Food Microbiology, v.93, p.101-107, 2004.

VAAMONDE, G. et al. Variability of aflatoxin and cyclopiazonic acid production by Aspergillus section flavi from different substrates in Argentina. International Journal of Food Microbiology, v.88, p.79-84. 2003. Available from: $<$ http://www. sciencedirect.com/science/article/pii/S0168160503001016>. Accessed: Fev. 15, 2008. doi:10.1016/S0168-1605(03)00101-6. 